\title{
Recanalization of chronic total coronary artery occlusions - the role of multi-slice computed tomography. Case report
}

Udrożnienia przewlekłych okluzji tętnic wieńcowych - rola wielorzędowej tomografii komputerowej. Opis przypadku

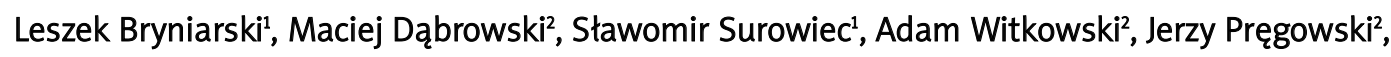 \\ Kalina Kawecka-Jaszcz ${ }^{1}$ \\ 1 Department of Cardiology and Hypertension, Jagiellonian University Medical College, Cracow, Poland \\ 2Department of Cardiology and Interventional Angiology, Institute of Cardiology, Warsaw, Poland
}

Post Kardiol Interw 2011; 7, 3 (25): 272-276

DOI: $10.5114 /$ pwki.2011.24749

\begin{abstract}
Non-invasive diagnostics of the heart allow one to assess myocardium viability (indication for procedure) and facilitate the choice of strategy and tools used during percutaneous coronary intervention ( $\mathrm{PCl}$ ). We present a case of $\mathrm{PCl}$ of chronic total occlusion (CTO) after non-invasive diagnostics, including multi-slice computed tomography (MSCT).
\end{abstract}

Key words: chronic total occlusion, percutaneous coronary intervention, multi-slice computed tomography

\section{Streszczenie}

Nieinwazyjne metody obrazowania serca pozwalają ocenić żywotność miokardium (ocena wskazań do zabiegu) oraz ułatwić wybór strategii zabiegu i sprzętu stosowanego podczas przezskórnej interwencji wieńcowej (ang. percutaneous coronary interventions, PCI). Przedstawiamy opis zabiegu u pacjenta poddanego PCI przewlekłej okluzji tętnicy wieńcowej po diagnostyce metodami nieinwazyjnymi, w tym po wykonaniu wielorzędowej tomografii komputerowej (multi-slice computed tomography, MSCT).

Słowa kluczowe: przewlekłe okluzje tętnic wieńcowych, przezskórne interwencje wieńcowe, wielorzędowa tomografia komputerowa

\section{Introduction}

Chronic total occlusions (CTO) still remains a great challenge for interventional cardiologists. However, owing to increasing operator experience, the use of modern tools and the proper qualification, percutaneous coronary interventions of CTO in the most experienced centres exceeds $90 \%$ of all cases. This success is also due to noninvasive imaging, which not only enables the viability of the myocardium in the area supplied by the occluded artery to be assessed (the assessment of indication for revascularization), but also facilitates the choice of the procedure strategy and tools used for the intervention. We present a patient who underwent $\mathrm{PCI}$ of CTO after previous non-invasive imaging diagnostic procedures (ECG, cardiac perfusion scintigraphy, and multi-row computed tomography).

\section{Case report}

The patient, aged 62 years, with hypertension, lipid abnormalities and type 2 diabetes, complained about persistent anginal symptoms in CCS class II despite optimal medical therapy. Five years ago the patient experienced severe anginal pain, which lasted several hours - the patient did not attend a medical visit.

Cardiac perfusion scintigraphy (SPECT) with dipyridamole revealed perfusion deficit in the anterior wall (mild in the basal segment and severe in the apical segment) as well as very severe perfusion deficit in the apex (fig. 1). Resting ECG revealed neither signs of ischaemia nor pathological Q waves (fig. 2).

Prior to the procedure, multi-row computed tomography was performed, which revealed occlusion of the left anterior descending artery in the mid segment. The length

Corresponding author/Adres do korespondencji:

Prof. Leszek Bryniarski MD, PhD, I Department of Cardiology and Hypertension, Jagiellonian University Medical College, 17 Kopernika, 31-501 Krakow, Poland, tel.: +48 1242473 00, e-mail: I_bryniarski@poczta.fm

Praca wpłynęła: 30.07.2011, przyjęta do druku: 30.08.2011. 


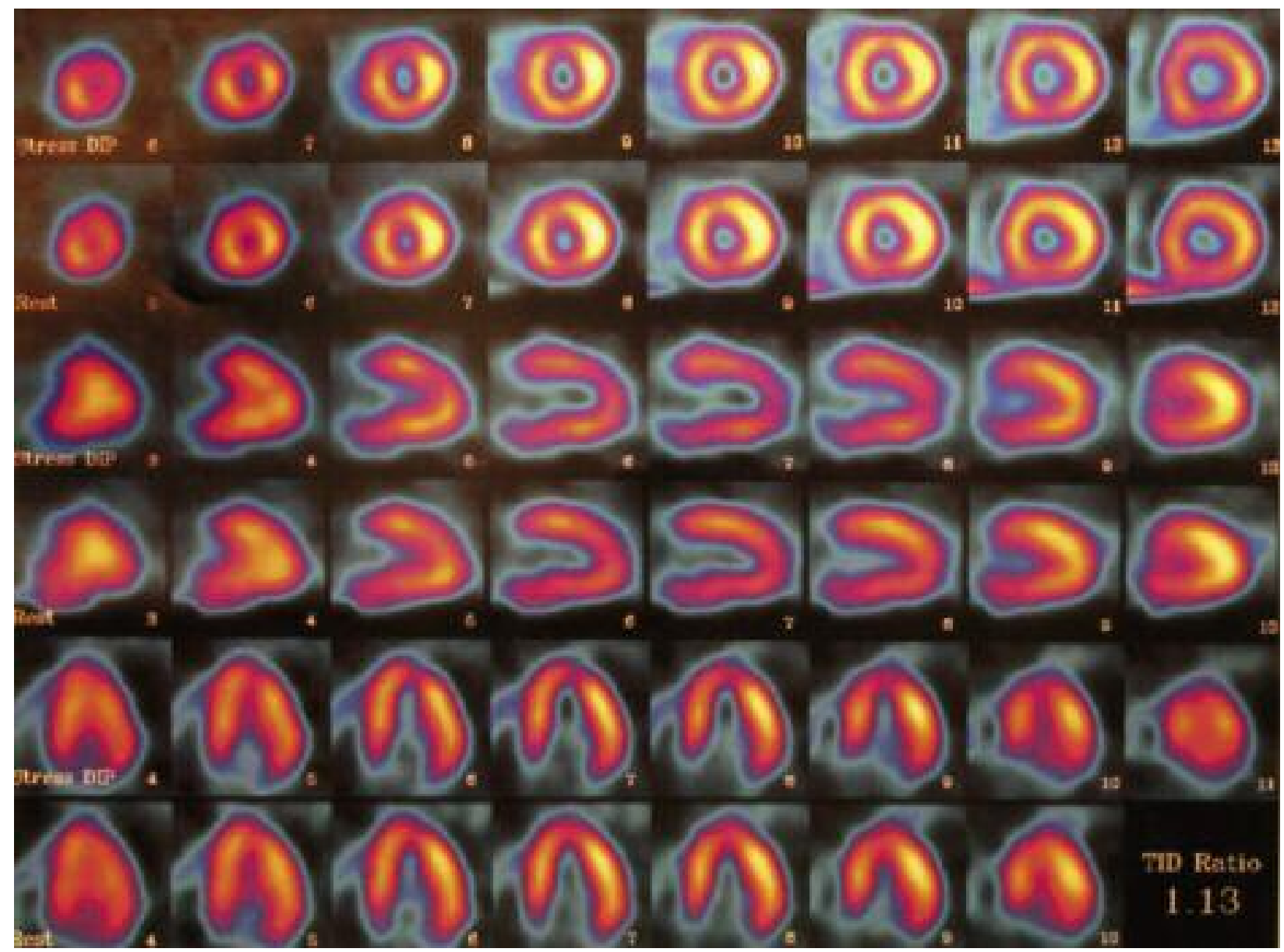

Fig. 1. Myocardial perfusion scintigraphy showed hypoperfusion of anterior wall and apex Ryc. 1. Scyntygrafia perfuzyjna serca wykazała hipoperfuzję ściany przedniej i koniuszka

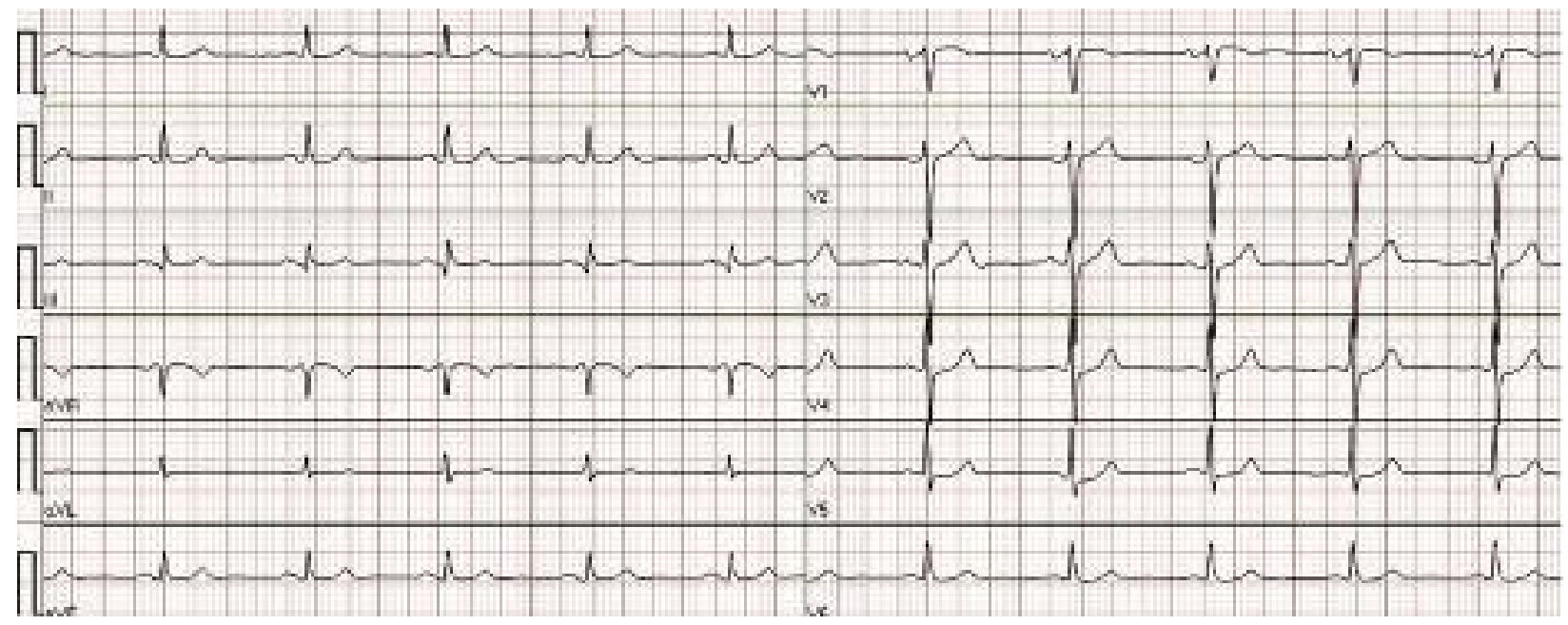

Fig. 2. No Q waves were found in V1-V4 leads

Ryc. 2. W EKG nie stwierdzono załamków Q w odprowadzeniach V1-V4 

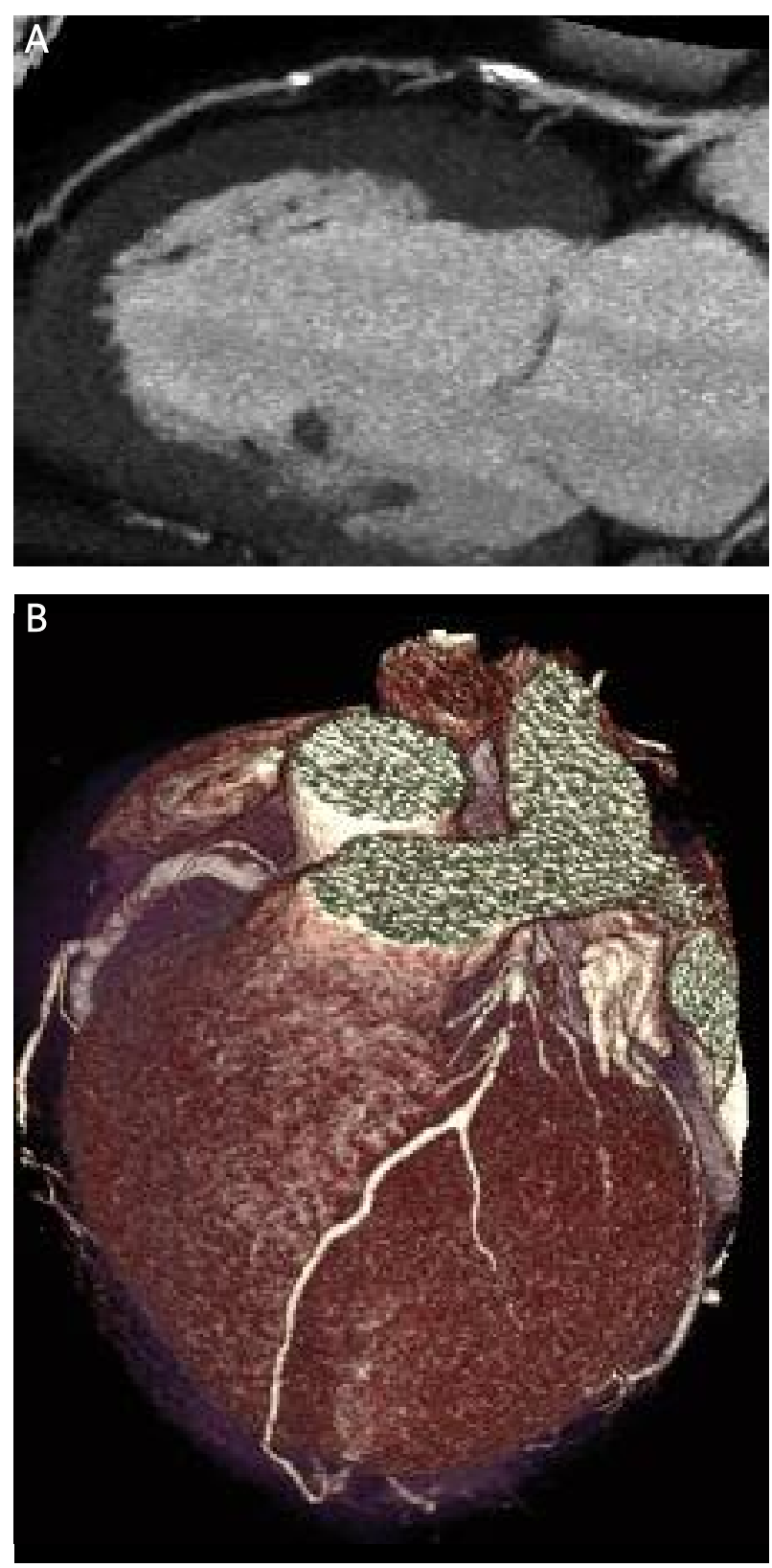

Fig. 3 A-B. Pictures from MSCT allowed us to assess length of occlusion and showed calcification in proximal part of occlusion

Ryc. 3 A-B. Tomografia komputerowa pozwolita ocenić dtugość zwężenia oraz obecność zwapnień w proksymalnej części okluzji

of the occlusion was estimated as $17 \mathrm{~mm}$, and a small calcification was described proximal to the occlusion site. The peripheral part of the left anterior descending (LAD) artery (distal to the occlusion) was easily seen. Calcifications were present proximal to the occlusion site, but neither in the proximal nor in the distal cap were calcifications present (fig. 3). On coronary angiography, the occlusion was rounded in shape, and in one view a stump was seen.
Coronarography revealed occlusion in the mid part of the LAD. The distal part of the LAD was supplied from collateral circulation originating from the right coronary artery. Both femoral arteries were punctured. Into the right femoral artery, a long $(40 \mathrm{~cm}) 7 \mathrm{~F}$ reinforced sheath was introduced in order to give better support. Into the left femoral artery, a $6 \mathrm{~F}$ sheath was introduced.

For contralateral injection, the right Judkins 4.0, $6 \mathrm{~F}$ diagnostic catheter was used. The left coronary artery was cannulated with the guiding catheter EBU 4.0, 7 F. The microcatheter QuickCross and the guide wire Fiedler XT $(300 \mathrm{~cm})$ were used. After crossing the occlusion, several balloon inflations were performed using a balloon catheter $1.5 \mathrm{~mm} \times 10 \mathrm{~mm}$, followed by $2.0 \mathrm{~mm} \times 15 \mathrm{~mm}$ with the maximum pressure of 10-12 atm. A drug-eluting stent $3.0 \mathrm{~mm} \times 18 \mathrm{~mm}$ was implanted (12 atm). It was postdilated using a non-compliant balloon $3.5 \times 12$ (16 atm) and the optimal effect was achieved. The stent size was adjusted on the basis of intracoronary ultrasound (ICUS). The time of the procedure was $55 \mathrm{~min}, 350 \mathrm{ml}$ of contrast agent was used, and the radiation dose was 5275 mGy.

\section{Discussion}

Multi-slice computed tomography (MSCT) in patients with chronic total occlusions enables, when compared to coronarography, further information to be obtained, which increases the success rate of the procedure [1]. The MSCT enables the assessment of the localization and the length of occlusion, assessment of the presence and extent of calcifications, the presence of side branches, and the side branches' angulation. It also enables three dimensional visualization of the course of the vessel (evaluation of tortuosity). Those parameters are also predictors of the procedure success. The extent of calcifications in the occlusion is of particular value. The extent of calcifications is associated with the age of occlusion: a small amount of calcium, as well as elastin and collagen, and large cholesterol burden, indicate occlusions with the age $<1$ year. In older occlusions, the extent of calcium, collagen and elastin exceeds $25 \%$ [2]. Calcification $>50 \%$ of the vessel diameter is a strong predictor of an unsuccessful procedure [3], increases the rate of complications and stent underexpansion, and correlates with the restenosis rate. The localization of calcification within the occlusion is also of importance. Severe calcification of the proximal occlusion site makes a successful PCI more possible when a retrograde approach is used [3].

Moreover, computed tomography enables measurement of the vessel diameter to be performed, making the stent selection easier. Owing to information obtained in the study, it is possible to adjust the optimal strategy of the procedure. In the present case, the information about the absence of calcifications in the MSCT in the proximal occlusion cap was the main factor determining the choice of the Fiedler XT guide wire. 


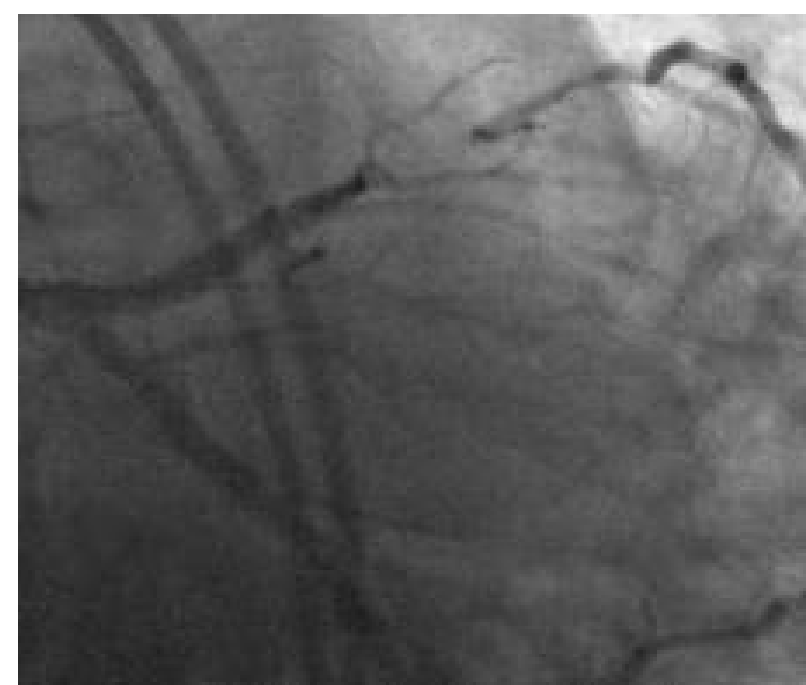

Fig. 4. Injections of contrast medium to both coronary arteries allow one to asses length of occlusion Ryc. 4. Jednoczesne podanie kontrastu do obu tętnic wieńcowych pozwala precyzyjnie ocenić długość okluzji w $L A D$

The Fiedler guide wires have an elastic tip coated with a hydrophilic polymer. They are very slippery guide wires, but they are also characterized by very good steerability. In the Fiedler XT guide wire, the length of the part coated with polymer is $16 \mathrm{~cm}$, and the tip of a diameter of 0.009 " is tapered. It enables one to increase the penetrating strength together with the smaller tip resistance, which results in a higher rate of successful revascularizations [4]. This is confirmed by data from the EuroCTO Club which associates experienced operators performing opening of coronary artery occlusions. The rate of procedures in which hydrophilic guide wires were used increased from $25 \%$ in 2006 to 55\% in 2010. Moreover, in 2011 the highest rate of successful PCI of CTO (41\%) was achieved with the use of $<1 \mathrm{~g}$ guide wires, with the Fiedler XT being the most commonly used. In $25 \%$ of cases of successful procedures, guide wires of $>9 \mathrm{~g}$ were used [5]. This figure describes the stiffness of a guide wire: it is the weight (in grams), placed $10 \mathrm{~mm}$ from the tip of the guide wire, which causes the tip to deflect. Therefore, paradoxically, guide wires with the lowest stiffness are of the greatest importance in $\mathrm{PCl}$ of CTO. Obviously, crossing through the proximal and distal fibrous cap sometimes necessitates the use of a stiffer guide wire, but for passing the occlusion the better choice is a hydrophilic guide wire. After crossing through the occlusion site, it is always necessary to visualize the distal part of the vessel, in order to confirm the localization of the guide wire in the true vessel lumen, and - as demonstrated in the present case - it is often necessary to use contralateral injection.

Because of the high restenosis rate in CTO, after inflations with a balloon catheter, it is necessary to implant a drug-eluting stent. It enabled the restenosis rate and

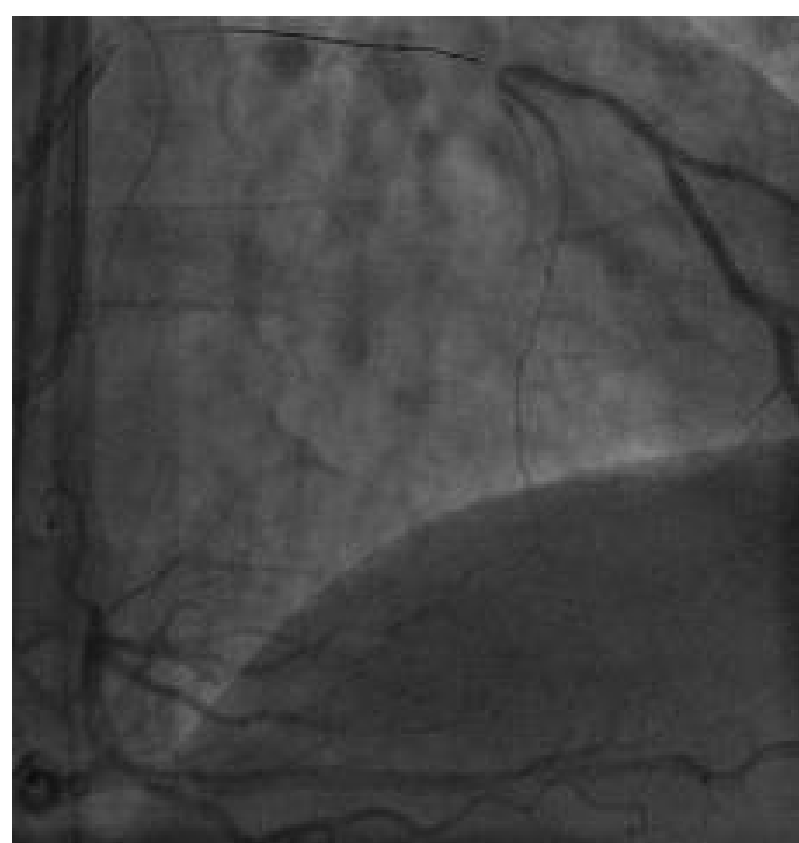

Fig. 5. Contralateral injection of contrast medium confirmed position of guidewire

Ryc. 5. Kontralateralne podanie kontrastu pozwala na potwierdzenie położenia prowadnika

the MACE (major adverse cardiac events) rate to be substantially reduced when compared to bare metal stents, including in the long-term follow-up [6].

The role of intracoronary ultrasound in $\mathrm{PCl}$ of CTO is of paramount importance. The ICUS can be used to assess the vessel diameter before stent implantation and for optimization of the final effect (ICUS optimized stent deployment), to assess the origin of the occluded artery, and the localization of a guide wire (true or false vessel lumen). In the present case, the use of ICUS prior to stent implantation enabled the true diameter of the vessel to be assessed, and the correct size of the stent to be chosen.

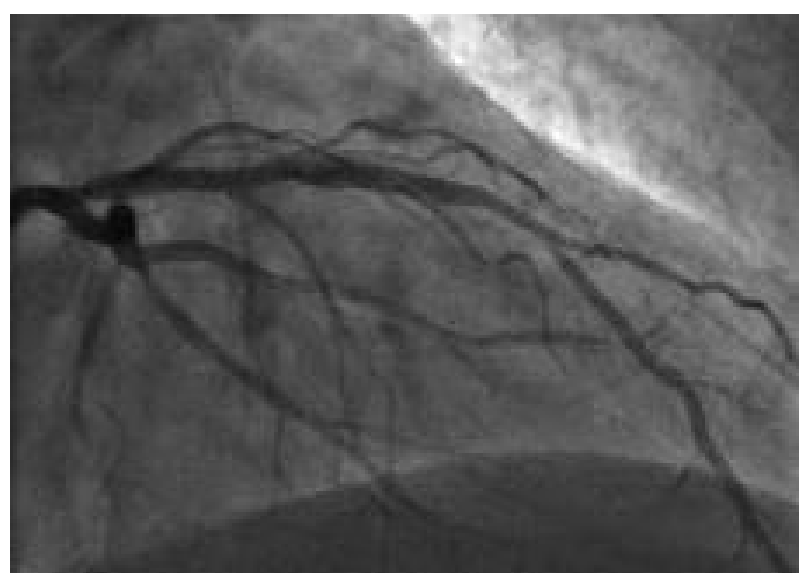

Fig. 6. Optimal effect after stent implantation Ryc. 6. Efekt po implantacji stentu 
In the second part of the procedure, ultrasound was used to optimize the effect of the procedure (ICUS guided stent deployment) [7]. According to some researchers (e.g. Gary Mintz), PCI of CTO should not be performed without ICUS study.

In conclusion, the benefits of using computed tomography prior to $\mathrm{PCl}$ of CTO are indisputable: the possibility to discuss and consult the strategy of the procedure (better arrangement for $\mathrm{PCl}$ of (TO), the better choice between antegrade vs. retrograde approach, the better choice of a suitable guide wire, the assessment of calcifications (the need for higher deployment pressures or rotablation), the better choice of stent size as well as the assessment of instent restenosis [2]. However, the use of computed tomography study prior to $\mathrm{PCl}$ of CTO is about 4-6\% [5]. It is obviously associated with the limitations of this study. Among other factors, the following need to be mentioned: the inability of direct flow assessment in the vessel or intervention during the study, difficulties in stenosis assessment in the case of heavy calcifications, the differentiation of subtotal stenosis (99\%) vs. occlusion, and the inability to visualize collaterals. Moreover, it is associated with exposure of the patient to an additional amount of contrast agent (100-150 ml) and an additional dose of radiation (8.5-15 $\mathrm{mSv}$ ). Therefore, the risk of contrast nephropathy and the exposure to ionizing radiation should be closely evaluated in the context of the possible benefits, and discussed with the patient.

\section{References}

1. Kaneda H, Saito S, Shiono T, et al. Sixty-four-slice computed tomography-facilitated percutaneous coronary intervention for chronic total occlusion. Int J Cardiol 2007; 115: 130-132.

2. Magro M, Schultz C, Simsek C, et al. Computed tomography as a tool for percutaneous coronary intervention of chronic total occlusions. Eurolntervention 2010; 6 Suppl G: G123-G131.

3. Soon $\mathrm{KH}, \mathrm{Cox} \mathrm{N}$, Wong A, et al. CT coronary angiography predicts the outcome of percutaneous coronary intervention of chronic total occlusion. J Interv Cardiol 2007; 20: 359-366.

4. Mitsudo K, Yamashita T, Asakura Y, et al. Recanalization strategy for chronic total occlusions with tapered and stiff-tip guidewire. The results of CTO new techniQUE for STandard procedure (CONQUEST) trial. J Invasive Cardiol 2008; 20: 571-577.

5. www.eurocto.eu.

6. Rahel BM, Laarman GJ, Kelder JC, et al. Three-year clinical outcome after primary stenting of totally occluded native coronary arteries: a randomized comparison of bare-metal stent implantation with sirolimus-eluting stent implantation for the treatment of total coronary occlusions (Primary Stenting of Totally Occluded Native Coronary Arteries [PRISON] II study). Am Heart J 2009; 157: 149-155.

7. Bryniarski L. Udrożnienia przewlekłych okluzji tętnic wieńcowych pod kontrolą ultrasonografii wewnątrznaczyniowej z wykorzystaniem pomiaru rezerwy wieńcowej. Rozprawa habilitacyjna, Kraków 2005. 